\title{
Wetland Square, Market Pier: Designing for heritage in the New Zealand regional landscape
}

\section{A peripheral problem}

From swampland through farmland to urban sprawl, the regional landscapes which once lay quietly at the peripheries of our cities are now experiencing radical urban growth and drastic environmental degradation. In the last 150 years, it is estimated that $90 \%$ of New Zealand's indigenous wetlands and swamp forests have been destroyed in the face of development (Robertson, 2015: 1). With wetlands drained, streams channeled and riverbanks stripped of their protective riparian forest, New Zealand's lowland ecosystems have suffered extensive and irreparable damage. The speed of this landscape transformation is so drastic that the changes which took place across just one century in New Zealand occurred over four in North America, and twenty in Europe (King, 2010: 26).

The Kāpiti Coast District, lying at the north-western reaches of the Greater Wellington Region, is identified as an appropriate case study to investigate the environmental and urban transformation typical of New Zealand's regional landscapes. Historically known as the 'Great Swamp', Kāpiti was once inhabited by Māori iwi, who settled near estuary mouths and on suitable mounds and spurs in the swamplands. Unearthed remains of eel weirs and sunken canoes unlock a not-so-distant past in which a navigable inland coastal water canoe passage was said to have stretched 30 kilometres between Paekakariki and Waikanae (Baldwin, 1993: 39). Following the arrival of European settlers to the region in the 1880s, Kāpiti has since evolved into a new type of regional landscape-one dominated increasingly by big-box retail centres, low-density residential development, and extensive farming pasture. Currently home to 51,400 residents, it is anticipated that Kāpiti's population will grow to almost 60,000 by 2040 , increasing by $20 \%$ (Statistics New Zealand). To accommodate this growth, the local council has stipulated 2400 new households in the form of greenfield development ${ }^{1}-$ a strategy that will only exacerbate urban sprawl-induced problems such as car reliance and wetland eradication. 


\section{A compelling alternative}

Prompted by these challenges, and in search of community and ecological resilience, this research sets out to investigate alternative strategies for urban settlement in the Kāpiti regional landscape. How can architecture reconcile a threatened, dynamic wetland system, a volatile urban condition, and an overlooked cultural history of indigenous settlement to ensure community and ecological resilience ${ }^{2}$ in the low-lying regional landscape? Among the suburban patchwork of lawns and single houses on Waikanae Beach lies an opportunity for architecture to respond critically and innovatively. At Waimeha Lagoon, an uncanny square 'conservation' wetland sits grid-locked by streets and unkempt residential fences, alluding to New Zealand's suppressed history of lowland European colonisation and subsequent environmental marginalisation. Inspired by this narrative, Wetland Square, Market Pier is a speculative site-specific design project for Waimeha Lagoon. The scheme proposes a new public platform to act as the catalyst for the wetland's transformation into a new town squarea new, but historically significant civic heart for the region. Through increasing population density and urban vitality, Wetland Square, Market Pier aims to reactivate and celebrate the natural and cultural history of a remnant wetland and its associated ecosystem.

Fig. 1 Google Earth (2010). Waimeha Lagoon, Kāpiti, New Zealand [Satellite Image]

Fig. 2 Author (2015). An early conceptual image illustrates the dichotomy between New Zealand's imported colonial history and its own unique natural history; A European Town Square is juxtaposed against New Zealand indigenous wetland plants [Digital Collage]
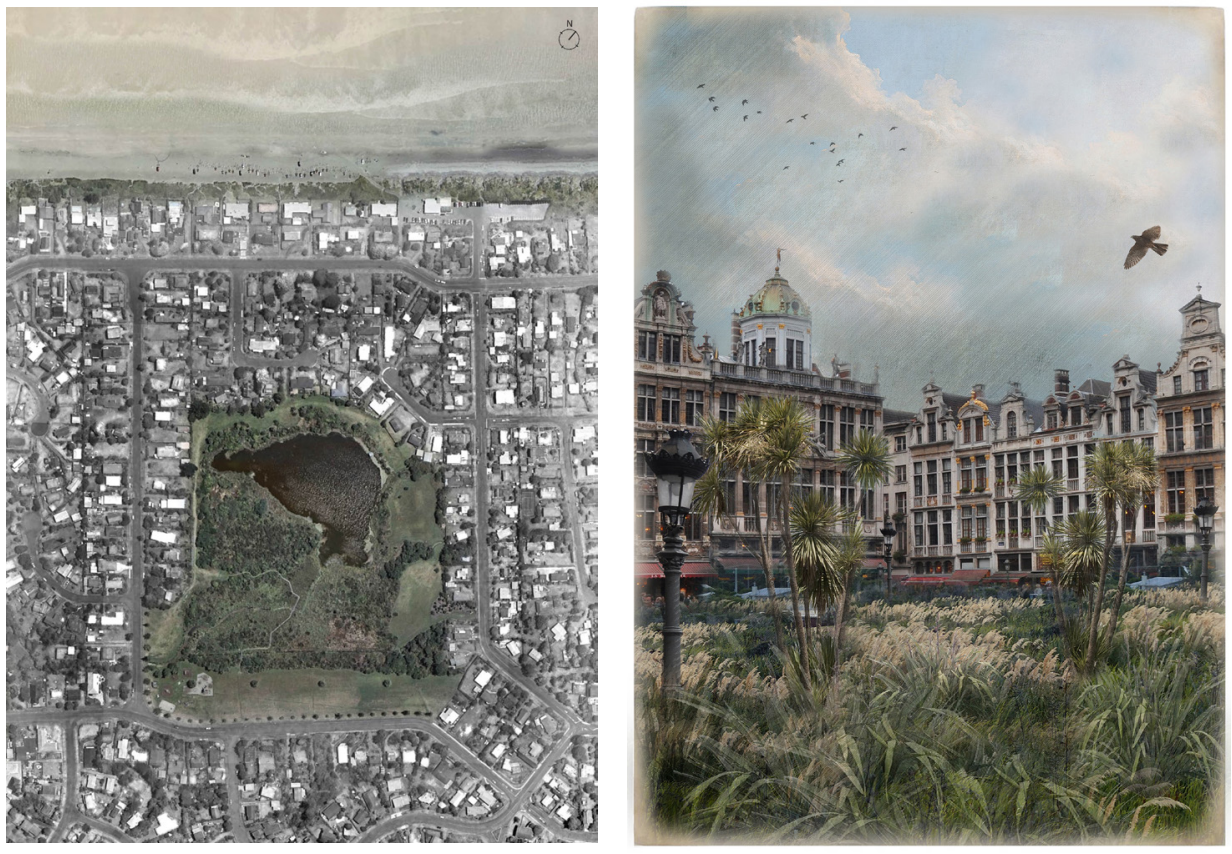

\section{A market pier}

Extending from a proposed new street edge, Market Pier is a porous 100 metre long, 12 metre wide platform connecting the lagoon edge and the town centre, acting as an ecotone between urban and natural systems. At the urban end of the pavilion is a permanent food market. Market stalls are rented to small gourmet restaurant outlets or produce shops. Dining rooms are located above, sheltered by a long ramped platform enabling views out to the offshore Kāpiti Island. The food market connects the new town centre with the wider agricultural activity of the region, referencing the historic function of the wetland as an important food and plant source. At the lagoon end, rentable and private kayaks are stored 
in lockable open-air shelves. Finally, the three separate walkways meet before the pier dives into the water, forming a launch pad for kayaks and referencing a local history of waka travel in the wetlands. The building's distinctive inclination from urban edge down to water's edge emphasises that this is not simply a landscape 'lookout' but a working pier, reactivating the landscape and functioning as an integral component of urban life.

Fig. 3 Author (2015). Market Pier: Roof Plan, elevation and ground floor plan [Composite Digital]

Fig. 4 Author (2015). Market Pier Perspective: Approaching from the proposed new street [Composite Digital]
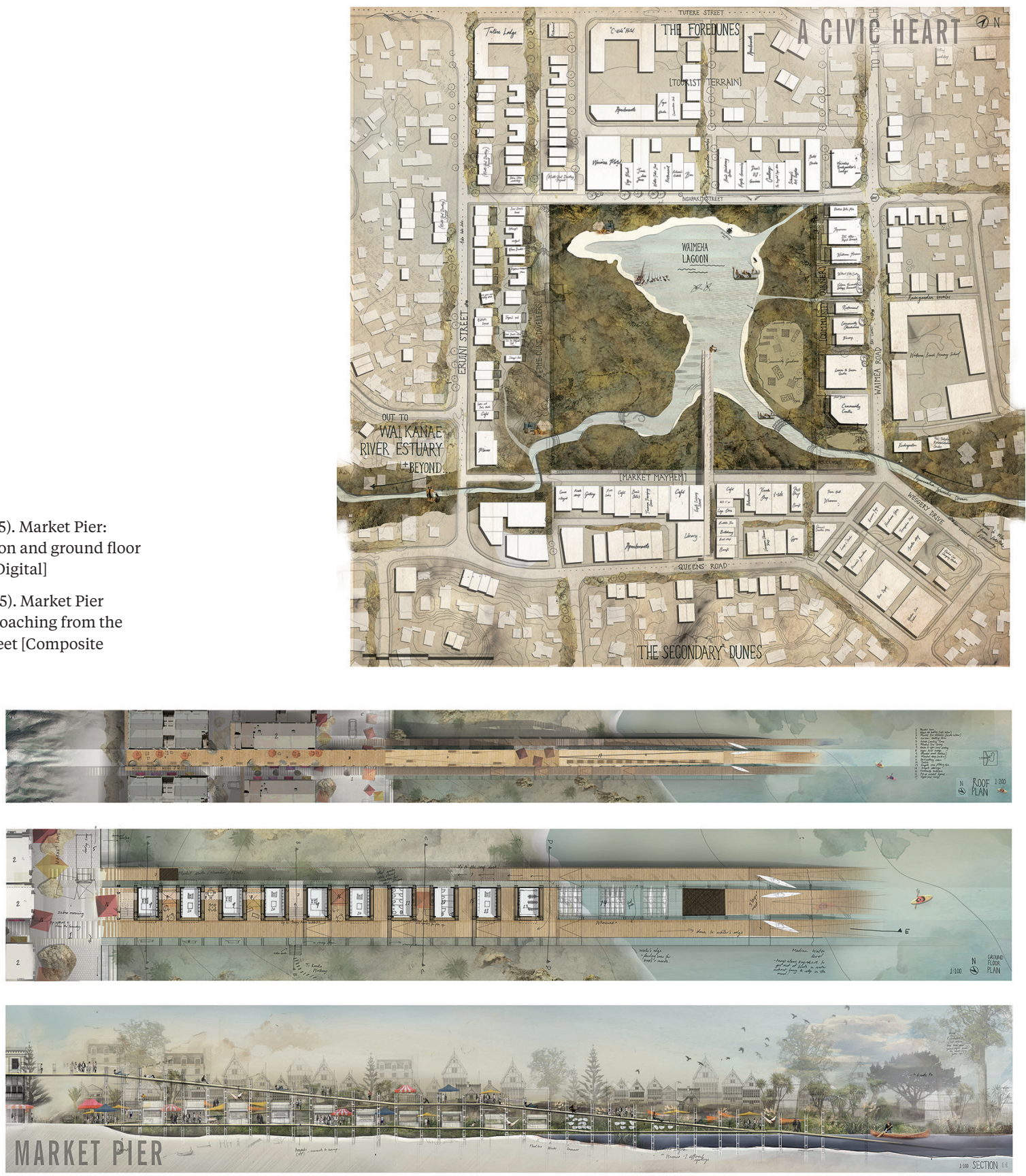
Fig. 5 Author (2015). Masterplan of Waimeha Wetland Square [Composite Digital]

\section{A wetland square}

The scheme exploits the unusual square frame of the existing urban landscape, transforming the wetland into a new town square, and centre for the scheme's proposed medium-density intensification. The concept pays homage to New Zealand's colonial history, taking precedent from a quintessentially European town square but with a clear difference: new 3-5 storey mixed-use buildings overlook a dynamic landscape, rather than a static square of pavement. Where many cities retain their heritage through protecting the built environment, this scheme emphasises that New Zealand's heritage is more strongly linked to its landscapes, its native flora and fauna, and the significance established by the first indigenous Maori settlers.

To transform the square, the perimeter of private fences is replaced with a ring of public boardwalks and shared streets, acting as a threshold between urban life and wild life. The design addresses the conflict between urbanism's desire for hard edges and the wetland's natural tendency for curved edges through proposing hardscaped shared streets and tightly clustered buildings on only two sides of the square. On the alternate sides, elevated timber boardwalks support a more porous urban grain while allowing for the wetland lagoon's movement. Key urban design principles are proposed for the buildings, including wetland-fronting orientation, narrow plot size and facade symmetry. To strike a balance between building variation and cohesiveness, different architects would be selected to design each building, while one master planner would govern the overall design quality and character of the Wetland Square.

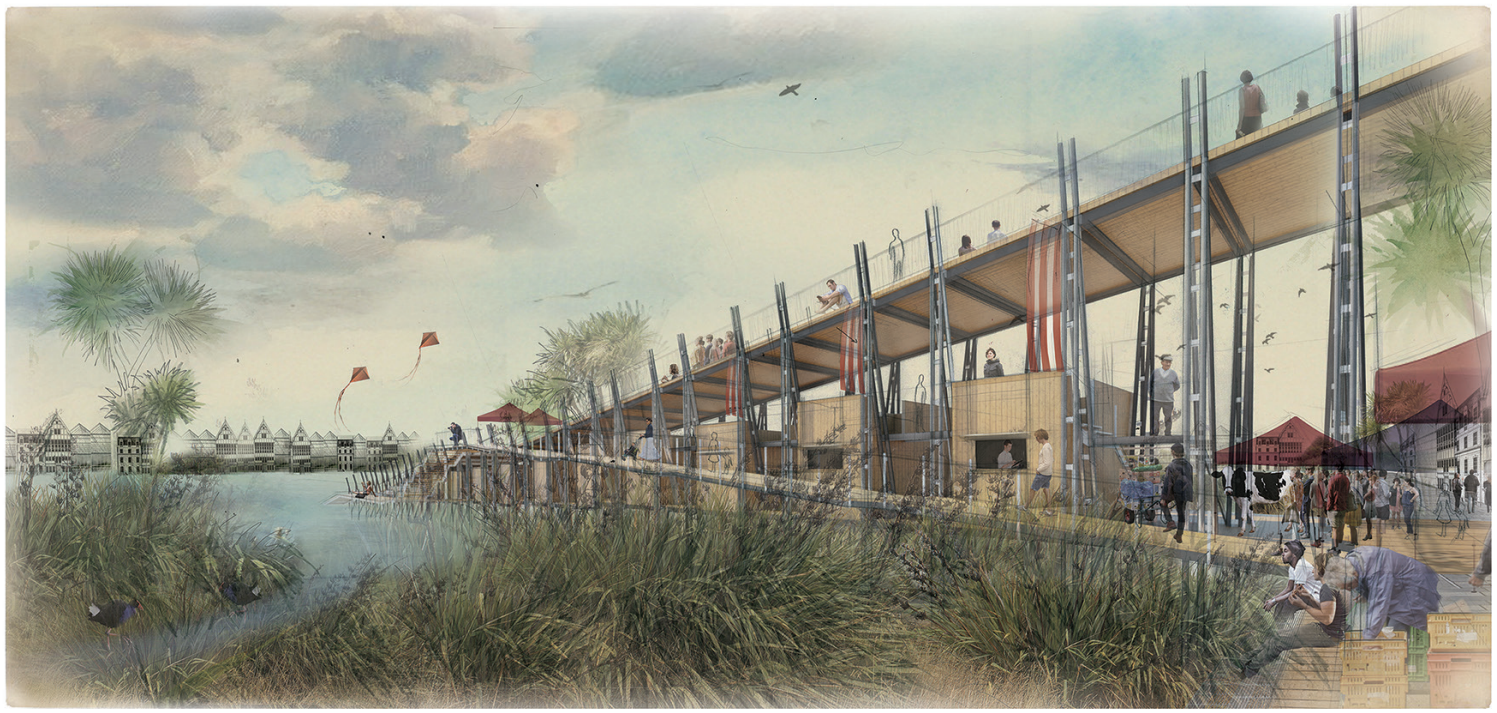

An Archetype for the Regional Landscape

Together, the Wetland Square and Market Pier act as a system which could be applied to other squared-off urban wetlands in the regional landscape. In particular, two similar sites identified in the neighbouring suburbs of Otaihanga and Paraparaumu Town present suitable opportunities to promote urban intensification, restore wetland quality and strengthen place identity. At a macro scale, the project proposes to link these urban wetland squares by restoring the region's former wetland network. In the way that interconnected wetlands once enabled inland canoe travel for Maori settlers, revitalised wetlands could act as spines for 
Fig. 6 Author (2015). A regional wetland network [Composite Image] associated recreation walking and biking trails, connecting the proposed town squares with each other, and the region's existing trail network. While Wetland Square and Market Pier are developed as the primary focus of this research, in reality they are envisaged as just one micro-component of a much greater urban and landscape heritage regeneration project.

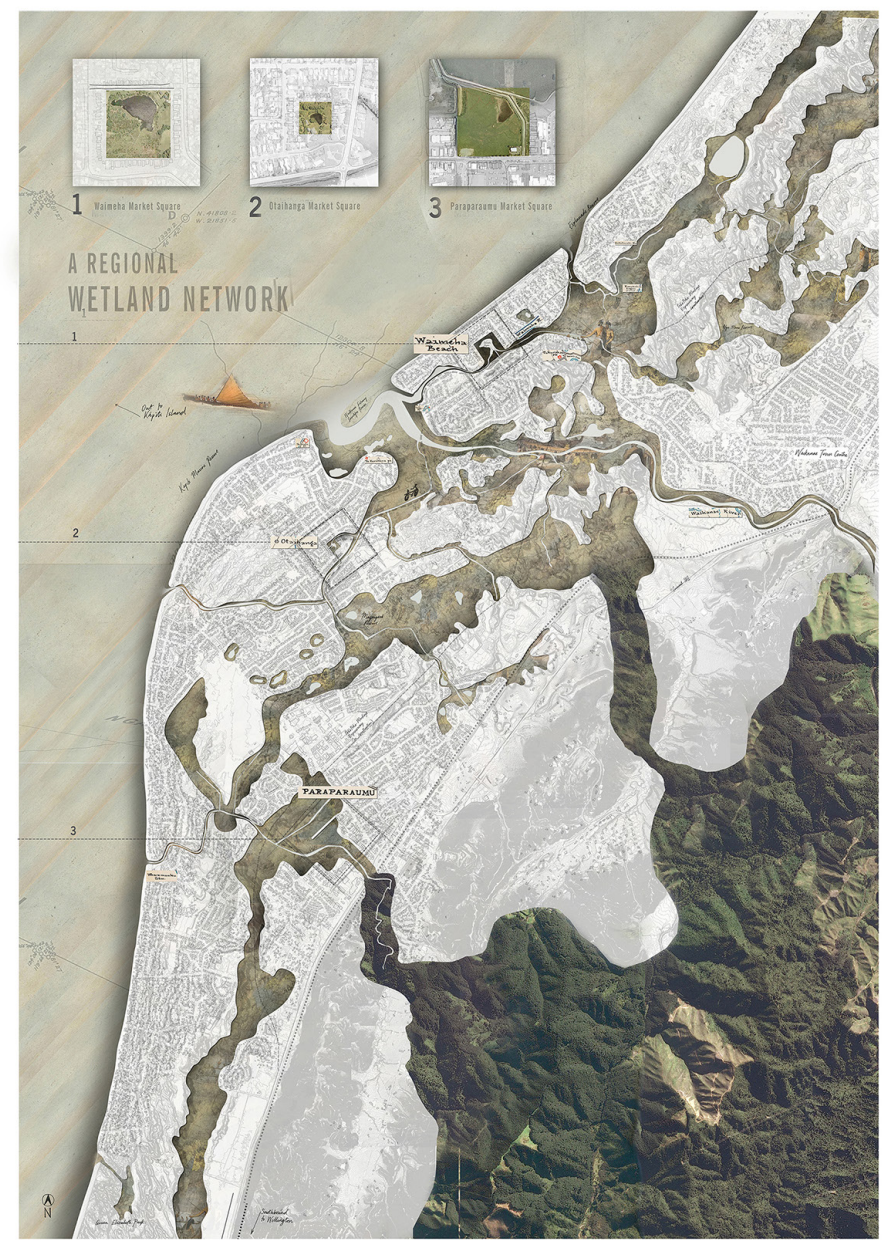


REFERENCES / ADDITIONAL READING

Baldwin, O. (1993). Kapiti

Coast: History of New

Zealand's Paraparaumu Beach, Paraparaumu Airport and Kapiti Island: Situated on the Western Coast of the Lower North Island. Paraparaumu [N.Z.]: Fields Pub. Housed in association with the Kapiti d'Urville Marathon Swim Book Charitable Trust.

Kapiti Coast District Council. District plan (Operative 2016). Retrieved from http://www. kapiticoast.govt.nz/Your-Council/ Planning/District-Plan1/DistrictPlan---Volumes-1-and-2/

King, M. (2010). The penguin history of New Zealand. Sydney: RHYW.

Park, G. (2007). Theatre country: Essays on landscape and whenua. Wellington, N.Z: Victoria University Press.

Park, G. (1995). Nga Uruora: The groves of life-Ecology and \& history in a New Zealand landscape. Wellington, N.Z: Victoria University Press.

Robertson, H. (2015). Wetland reserves in New Zealand: The status of protected areas between 1990 and 2013. New Zealand Journal of Ecology, 40.1, 1-11.

Statistics New Zealand (2013). Area unit population projections. Retrieved from http://nzdotstat. stats.govt.nz/wbos/Index.aspx

Taylor, K., Mitchell, N., \& St. Clair, A. (2014). Conserving cultural landscapes: Challenges and new directions. New York, NY: Routledge.

The United Nations Office for Disaster Risk Reduction (2007). Terminology. Retrieved from https://www.unisdr.org/we/inform/ terminology

Vakhitova, T. (2015). Rethinking conservation: Managing cultural heritage as an inhabited cultural landscape. Built Environment Project and Asset Management 5.2, 217-228. 